Canadian Journal of Higher Education

Revue canadienne d'enseignement supérieur

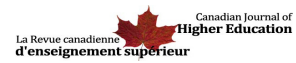

\title{
Human Capital or Cultural Taxation: What Accounts for Differences in Tenure and Promotion of Racialized and Female Faculty?
}

\section{Rochelle Wijesingha et Howard Ramos}

Volume 47, numéro 3, 2017

URI : https://id.erudit.org/iderudit/1043238ar

DOI : https://doi.org/10.7202/1043238ar

Aller au sommaire du numéro

\section{Éditeur(s)}

Canadian Society for the Study of Higher Education

ISSN

2293-6602 (numérique)

Découvrir la revue

\section{Citer cet article}

Wijesingha, R. \& Ramos, H. (2017). Human Capital or Cultural Taxation: What Accounts for Differences in Tenure and Promotion of Racialized and Female Faculty? Canadian Journal of Higher Education / Revue canadienne

d'enseignement supérieur, 47(3), 54-75. https://doi.org/10.7202/1043238ar
Résumé de l'article

Achieving tenure and promotion are significant milestones in the career of a university faculty member. However, research often indicates that racialized and female faculty do not achieve tenure and promotion at the same rate as their non-racialized and male counterparts. Using new original survey data on faculty in eight Canadian universities, this paper examines differences in tenure and promotion among racialized and female faculty and investigates the extent to which explanations of human capital theory and cultural or identity taxation account for these disparities. Logistic regression confirms that controlling for human capital and cultural or identity taxation washes away the differences between male and female faculty for achieving both tenure and promotion. However, differences for racialized faculty remain, thereby offering evidence of discrimination in the academic system.
Copyright (c) Rochelle Wijesingha, Howard Ramos, 2017

Attribution-NonCommercial-No Derivative Works 2.5 Canada
Ce document est protégé par la loi sur le droit d'auteur. L'utilisation des services d'Érudit (y compris la reproduction) est assujettie à sa politique d'utilisation que vous pouvez consulter en ligne.

https://apropos.erudit.org/fr/usagers/politique-dutilisation/ 
Canadian Journal of Higher Education Revue canadienne d'enseignement supérieur

Volume 47, No. 3, 2017, pages 54 - 75

\title{
Human Capital or Cultural Taxation: What Accounts for Differences in Tenure and Promotion of Racialized and Female Faculty?
}

Rochelle Wijesingha

McMaster University

Howard Ramos

Dalhousie University

\begin{abstract}
Achieving tenure and promotion are significant milestones in the career of a university faculty member. However, research indicates that racialized and female faculty do not achieve tenure and promotion at the same rate as their non-racialized and male counterparts. Using new survey data on faculty in eight Canadian universities, this article examines differences in being tenured and promoted between racialized and non-racialized faculty and between female and non-female faculty. It also investigates the extent to which explanations of human capital theory and cultural or identity taxation account for these disparities. Logistic regression confirms that controlling for human capital and cultural or identity taxation washes away the differences between being tenured and promoted for female faculty. Differences for racialized faculty remain, offering evidence of racial discrimination in the academic system.
\end{abstract}

\section{Résumé}

L'obtention de la permanence et la promotion sont des jalons importants de la carrière d'un professeur d'université. Cependant, des recherches scientifiques indiquent que les professeurs racialisés et les femmes n'obtiennent pas de permanence et de promotion au même rythme que leurs homologues non racialisés et de sexe masculin. En utilisant de nouvelles données provenant d'une enquête menée auprès de professeurs dans huit universités canadiennes, cet article scrute les différences entre les taux de permanence et de promotion des professeurs racialisés et non racialisés, ainsi qu'entre femmes et non femmes, afin d'analyser dans quelle mesure la théorie du capital humain ou celle de l'imposition culturelle ou identitaire explique ces disparités. La régression logistique confirme qu'en contrôlant le capital humain ou l'imposition 
culturelle ou identitaire, les différences de permanence ou de promotion parmi les femmes disparaissent. Cependant, même avec ce contrôle, les différences demeurent pour les professeurs racialisés, ce qui fournit une preuve que la discrimination raciale existe dans le système universitaire.

Achieving tenure and promotion are significant milestones in the career of a university faculty member. Park (2011) noted that apart from salary, they are the most important and lasting rewards available to academics. However, research shows that racialized faculty do not receive tenure and promotion at the same rate as non-racialized faculty, and women are less likely to gain tenure or be promoted compared to male faculty. Both relationships are evident despite the fact that Canada is becoming increasingly ethnically and racially diverse and an increasing number of university students, graduates, and professors are women.

In this paper, using original survey data on faculty in eight Canadian universities, we examined these trends by looking at two competing explanations offered in the research on tenure and promotion. The first is based on human capital theory, which accounts for disparities in career outcomes through differences in productivity of individual faculty members and years of experience. This perspective argues that if racialized and female faculty are less productive, then their lower rates of professional reward are justified. In contrast, another explanation for differences in tenure and promotion focuses on cultural or identity taxation of racialized and female faculty members. According to this perspective, minority and female faculty are over-burdened with higher teaching loads, mentoring, and service work, which inhibits productivity and ultimately leads to the denial of tenure and promotion. If this is the case, then minority and female faculty face discrimination in two forms: barriers hindering fair competition in the academic field and a lack of recognition of their contributions to the academy.

Unfortunately, most research looking at differences in the rates of tenure and promotion of racialized and female faculty are from the US and this research looks at either one or the other explanation in isolation. In part this is because of methodological differences employed by those examining each theory. Those focusing on human capital theory usually rely on large datasets and use statistical methods, whereas those looking at cultural or identity taxation tend to rely on small sample interview data. To our knowledge, few studies take both into account. For this reason we sought to understand which, if either, of these explanations accounts for differences in the rates of being tenured and promoted for racialized and female faculty in the Canadian context.

\section{Human Capital or Cultural Taxation?}

Many researchers have shown that racialized faculty receive tenure and promotion at lower rates than non-racialized faculty (Nakhaie, 2007; Nettles, Perna, Bradburn, \& Zimbler, 2000; Perna, 2001a; Ryu, 2008; Weinberg, 2008), and other research also demonstrates that racialized faculty earn less money (Li, 2012). The same can be said of women in the academy (CAUT [Canadian Association of University Teachers], 2008, 2010; Ginther \& Hayes, 2003; Harper, Baldwin, Gansneder, \& Chronister, 2001; Marschke, Laursen, McCarl Nielsen, \& Dunn-Rankin, 2007; Nakhaie, 2007; Ornstein, Stewart, \& Drakich, 1998; Perna, 2001a, 2005; Valian, 1998). What remains unanswered is, why is this the case? 
Human capital theory offers one possible explanation. It looks at the relationship between productivity, experience, and outcomes. In other words, following neoliberal logic, individuals who work harder and longer gain more benefit. In the world of academia, productivity is usually measured by research output and, as the old adage goes, "publish or perish." In fact, the number of publications and research grants gained by an academic are often used as a measure of research output (Chen \& Ferris, 1999; Cora-Bramble, Zhang, \& Castillo-Page, 2010; Perna, 2001b), and this is also the primary method used to evaluate faculty for tenure and promotion. As a result, one explanation for differences between racialized and non-racialized faculty and women compared to men is that racialized faculty and women are less productive or possess less human capital than their counterparts. However, with respect to the tenure and promotion of racialized and female faculty, accounting for such measures offers mixed results.

Some US research has shown that controlling for human capital measures of productivity account for much of the racial and gender disparities in the academic reward structure (Perna, 2001; Porter, Toutkoushian, \& Moore, 2008; Smart, 1991). For instance, a number of scholars in the US have found that racialized faculty have lower research productivity than non-racialized faculty (Bellas \& Toutkoushian, 1999; Jackson, 2008; Long \& Fox, 1995; Pearson, 1985; Toutkoushian, 1998). However, productivity differences of racialized faculty have not been examined in Canada. Literature on female faculty show similar patterns. Many studies in the US and Canada demonstrate that on average women often have less research output than male faculty (Evans \& Bucy, 2010; Hesli \& Lee, 2011; Larivière, Vignola-Gagné, Villeneuve, Gélinas, \& Gingras, 2011; Nakhaie, 2002). Nakhaie (2002) showed that Canadian male faculty out-publish female faculty across six measures of publication. Other US studies show female faculty receive fewer research grants (Larivière et al., 2011; Stack, 2004) and when they do receive research grants, they are less likely to be the principal investigator.

Other research coming out of the US, however, finds no difference in levels of research productivity between racialized and non-racialized faculty, and some racialized groups even out-publish White faculty (Bellas \& Toutkoushian, 1999; Jackson, 2004; Nettles \& Perna, 1995; Toutkoushian, 1998). For instance, Toutkoushian (1998) found that although Black faculty had lower levels of research output in comparison to White faculty, Asian faculty had higher levels of research output. Similarly, Bellas and Toutkoushian (1999) found that Latino faculty had higher levels of research output than White faculty

With respect to tenure and promotion as specific outcomes, results are equally mixed. Some research in the US has shown that controlling for human capital measures of productivity serves to decrease or eliminate racial or gender disparities in the academic reward structure (Perna, 2001a; Porter, Toutkoushian \& Moore III, 2008; Smart, 1991). However, other studies in Canada and the US have shown that accounting for productivity does not adequately explain the racial or gender disparities found in academic reward structures (Nakhaie, 2007; Perna, 2005; Toutkoushian, 1999). That is, despite controlling for human capital, racial and gender differences continue to exist.

In addition to productivity, human capital is also captured through looking at work experience in a job field (Galabuzi, 2006; Li, 1992, 2012; Pendakur \& Pendakur, 2002). The logic of looking at experience is that one gains specialized skills and increases productivity the longer they work in a specific job. A new professor has to build new courses and may be less aware of how publications and grants are refereed than a professor who has worked in his or her discipline for many years. This, in turn, means new academics 
are less likely to be as productive as a more seasoned academic. When years of experience and human capital are taken into account by Nakhaie (2007), he found that promotion to the rank of associate professor in Canada depended more on work experience than the number of publications. Li (2012), however, finds that income differences persist even after controlling for experience, which leads him to conclude that racialized and female faculty in Canada face discrimination after human capital is accounted for. The mixed findings with respect to human capital and racial and gender differences in academic rewards has led some to argue that human capital theory does not adequately explain disparities found in academic reward structures (Perna, 2001a; 2005; Toutkoushian, 1999). Instead, other factors might better account for academic outcomes.

This brings us to a second possible reason for the different patterns of academic reward for racialized and female faculty. The academic reward structure, as many have observed, is heavily based on research and less so on teaching and service (Fairweather, 1993; Henry \& Tator, 2012; Leslie, 2002). This means that faculty who focus on teaching, mentoring, community outreach, and administrative duties are at a disadvantage when it comes to tenure and promotion. With respect to racialized faculty, Padilla (1994) coined the term "cultural taxation" to explain why racialized faculty do not receive tenure and promotion at the same rate as non-racialized faculty. Cultural taxation refers to the added burden racialized faculty often confront as members of a limited pool of people who represent diversity within their academic faculties. For Padilla, cultural taxation includes serving on a number of committees to increase racial representation, and being called on as an expert on cultural and racial diversity. Others scholars, such as Joseph and Hirshfield (2011), have extended the types of cultural taxation to include heavier workloads that racialized faculty face, which include higher teaching loads and mentoring of students. Taxation occurs because students seek them out as of a small pool of faculty that may represent their own racialized experience or because non-racialized students who exoticize them.

Qualitative interviews with racialized faculty in Canada suggest that they also may feel an obligation to mentor other racialized and Indigenous students (Henry \& Tator, 2009; Spafford, Nygaard, Gregor, \& Boyd, 2006). Henry and Tator (2012) found this to be true among racialized faculty who often felt that they were overloaded with teaching and administrative work that left them with little time to publish. They also found that the same faculty members felt that they were asked to sit on more committees due to their ethno-racial backgrounds, a finding echoed by a number of other researchers from the US (cf. Jackson, 2004; Joseph \& Hirshfield, 2011; Odhiambo \& Charoenpanitkul, 2011; Villalpando \& Bernal, 2002).

Some scholars have also argued that female faculty face a similar form of taxation related to their gender calling it "identity taxation" (Hirshfield \& Joseph, 2012). Literature from the US has shown that female faculty have heavier teaching loads and spend more time on service activities and mentoring than male faculty (Hirshfield \& Joseph, 2012; Menges \& Exum, 1983; Misra, Lundquist, Holmes, \& Agiomavritis, 2011; Nettles et al., 2000; Samble, 2008). Women, like racialized faculty, are often asked to sit on multiple committees to increase gender representation (Menges \& Exum, 1983). Spending copious amounts of time on teaching, mentoring, and service has adverse effects on faculty productivity (Bellas \& Toutkoushian, 1999; Fairweather, 2002; Hattie \& Marsh, 1996; Hirshfield \& Joseph, 2012; Johnson \& Harvey, 2002; Joseph \& Hirshfield, 2011). Bellas and Toutkoushian (1999), for instance, determined that faculty who spent higher amounts of time on teaching and service produced less research products such as peer-reviewed arti- 
cles or grants. As already noted above, time spent mentoring students, teaching and doing administrative work is not as valued in the academy as time spent on research (Antonio, 2002; Henry \& Tator, 2012; Leslie, 2002; Padilla, 1994). Cultural or identity taxation may account for why racialized and female faculty produce less research output, but counter to human capital theory, it does not explain away differences in rates of tenure and promotion. In fact, it offers evidence of systemic discrimination.

As a result, this has left two competing perspectives for the lower rates of tenure and promotion among racialized and female faculty and two different conclusions. In our paper, we sought to examine which, if either, accounted for the academic outcomes, or rewards, of racialized and female faculty in eight Canadian universities. We did this by first examining whether racialized and female faculty are tenured or promoted at the same rate as non-racialized and male faculty. We then look at measures of human capital and cultural or identity taxation to see if they account for differences and then perform logistic regression analysis to look at additional controls and interactions.

\section{Methodology}

Examining tenure and promotion of racialized and female faculty in Canada is important for three reasons. First, Canadian research on tenure and promotion of female faculty is limited to a few studies (CAUT, 2008, 2010; Nakhaie, 2007; Ornstein et al., 1998, 2007; Stewart, Ornstein, \& Drakich, 2009) and the literature on racialized faculty is even more sparse (Henry, 2012; Henry \& Tator, 2012; Kobayashi, 2009; Monture, 2009; Nakhaie, 2007). Second, much of the Canadian research on tenure and promotion of racialized faculty is qualitative, employing a limited sample (exception: Nakhaie, 2007); to our knowledge, our analysis is one of the first large-scale quantitative studies looking at tenure and promotion among racialized faculty in Canadian universities. Third, we offer a rare study that looked at how both human capital and cultural taxation measures affect disparities in being tenured and promoted for racialized and female faculty.

To examine the effects of human capital and cultural or identity taxation on being tenured and promoted among racialized and female faculty, we conducted a new survey, the University Tenure, Promotion and Hiring (UTPH) survey ${ }^{1}$ with faculty employed at Canadian universities. The online survey consisted of 77 questions focused on perceptions of tenure, hiring, and promotion of faculty at universities. The survey's sampling frame was based on all publicly available emails listed on the websites of eight Canadian universities. The universities included represent English Canadian universities from Western Canada, the Prairies, Ontario and Atlantic Canada. Three of the universities represented large institutions, two represented smaller ones, and five were members of the U15, which are considered to be the country's most research intensive schools. The survey was emailed to 15,571 faculty (irrespective of rank or type of academic affiliation or position) and was selfadministered online. Participants were enumerated during the fall of 2013. The response rate was $16 \%$, of which $66 \%$ completed the entire survey. The response rate was in line with a similar study using the same methodology (see Jones, Weinrib, Metcalfe, Fisher, Rubenson, \& Snee, 2012). Although online surveys generally achieve lower response rates than mail surveys (Nulty, 2008), research shows that the representativeness of the sample is more salient than the actual response rate (Cook, Heath, \& Thompson, 2000). We will discuss the representativeness of the sample below when we discuss the results. The sample included both tenure-track and other faculty in enumerated U15 and teaching universities 
as well as institutions from all regions, save Quebec. The province of Quebec was excluded because francophone institutions have a different academic culture from English Canadian institutions, the cost of translation of the survey was prohibitive, and English institutions in Quebec are similar to others included in the sample. In future studies, we would encourage a broader sampling of schools.

We measured "racialized" faculty by asking if participants self-identified in any of the categories used by Statistics Canada's definition of visible minorities. ${ }^{2}$ The term visible minority is a contentious term (Synnott \& Howes, 1996) and therefore we, instead, have used the phrase "racialized" to recognize that visible minority categories are normative and are constructed in an ongoing process of power relations. We acknowledge that racialized people are not a homogenous population and that considerable variations exist within these populations. However, further disaggregation was not methodologically possible because of the limited sample size in each group. Participants were also asked if they identified as an Indigenous person. We combined those who identified as a visible minority and/or Indigenous person into a single category of racialized participants versus those who did not identify as either. We further acknowledge that Indigenous people are not usually considered the same as another ethnic or minority group in Canada due to their unique experience of colonization and history as "original peoples" (Comack, 2012, p. 64-65; Dua, 2008). We combined the two groups for two reasons: first, because both groups are underrepresented as faculty relative to their proportion of the population in Canada (see Ramos 2012), and second, because of the small number of participants who identified as Indigenous in this study $(n=35)$, it was difficult to perform a meaningful analysis if treated separately.

The variable "female" is measured by those who identified as such. In an attempt to be inclusive of faculty who did not identify with hetero-normative gender labels, we simply asked if participants identified with either male or female dominant labels in two yes/no questions. This allowed participants to identify as either, neither, or both. The strategy turned out to be less than ideal. The number of participants who identified as both or neither normative gender labels was too small $(n=21)$ to allow for a meaningful analysis. More important, a number of participants indicated that we did not capture gender well nor did we capture the experiences of transgender populations. Likewise, some participants who subscribed to hetero-normative labels complained that we overly complicated the question. In future research we recommend leaving gender questions open to allow for the widest possible responses and later aggregation.

In our analysis we examine two dependent variables that are measures of academic achievement, reward, or outcomes: tenure status and promotion to associate professor. While some treat tenure and promotion to associate professor as synonymous (Ornstein, Stewart, \& Drakich, 2007), our data demonstrated why it was important to look at both groups separately. For example, we had 113 respondents who were promoted to associate professor but were not tenured, and we had 78 respondents who were tenured but were not associate professors. Such situations occur in Canadian universities where tenure and promotion are not paired and in fields that appoint limited-term professors at higher ranks. For these variables, participants were asked to indicate whether they were tenured and whether or not they were promoted to associate professor. Both variables were dichotomous and therefore logistic regression was appropriate. Although each institution has its own standards for tenure and promotion and it would have been beneficial to control for the institution of the respondent, however, for the purpose of anonymity we 
did not ask participants in the survey to indicate which institution they came from and therefore could not control for it.

Human capital was measured by asking participants to estimate how many research grants they had won in the last five years and to estimate of how many refereed articles, book chapters, books, and edited books they published since they began working as a faculty member. Measuring the quality of a publication is difficult because of the highly subjective nature of what is considered "quality." Some might argue that journal rankings or impact factor measure quality; however, a publication in a high-impact factor journal does not necessarily equate to having broad resonance in the field, and the importance placed on specific journals varies by discipline and subfield. For these reasons we looked at counts. The variable for articles was positively skewed and for this reason quintiles were created to allow for simpler analysis. We used the top quintile as the reference category for each. Another measure of human capital is years of service. This was measured by asking respondents to indicate what year they began working at a university as a faculty member. We then subtracted the current year of the survey from the year hired. Again quintiles were created to allow for easier analysis and the top quintile was used as the reference category. Cultural (or identity) taxation was measured by examining faculty perceptions of teaching load, supervision of graduate students and administrative load. Participants were asked whether each was "lower," "the same," or "higher" compared to their colleagues. We combined "the same" and "lower" to compare against "higher."

In addition to these measures we controlled for academic discipline. Previous research suggests that racialized faculty tend to be concentrated in particular disciplines, such as engineering, computer science, medicine, and science (Dua \& Bhanji, 2012; Henry, Choi, \& Kobayashi, 2012; Henry \& Tator, 2012; Stewart, 2009). Literature also suggests that female faculty are also concentrated in traditionally feminized fields such as nursing, education, and English (Harper et al., 2001; Nettles et al., 2000) and are less likely to work in science, technology, engineering, or mathematics (CAUT, 2008; Etzkowitz, Kemelgor, \& Uzzi, 2000; Perna, 2005). Moreover, we felt it was important to control for discipline because of differences across fields in rates of promotion. Ornstein, Stewart, and Drakich (2007) found that particular disciplines such as science, engineering, and professional schools promoted their faculty more rapidly and disciplines such as journalism, nursing, and other health professions took longer than average. Academic discipline was measured by asking participants to list what field they worked in and responses were then coded into 10 dummy categories, including sciences, engineering, business, medicine, health, social sciences, arts, education, law, and other disciplines (which we used as the reference category).

We also controlled for immigrant status because a large proportion of racialized people in Canada are immigrants. According to the 2011 National Household Survey, immigrants comprised $21 \%$ of the total Canadian population, which was the highest among the G8 countries (Statistics Canada, 2013). Of the 19\% of people who identified as visible minorities, 65\% were immigrants (Statistics Canada, 2013). Immigrant status was measured by asking respondents to indicate whether they currently are, or ever were a landed immigrant. It should be noted that immigrants also include non-racialized individuals.

To assess the effects of human capital and cultural or identity taxation on being tenured and/or promoted among racialized and female faculty we used tabular and logistic regression analysis. In the following section we present our analysis and results. 


\section{Analysis and Results}

We began by looking at some of the demographic attributes of participants. The survey sample was fairly representative of university faculty in Canada. Fifteen percent of participants in the survey identified as racialized (234 out of 1580), which was similar to the $16 \%$ of professors identified in the 2006 census $^{3}$ (Li, 2012; Ramos 2012). Forty-six percent of survey participants identified as female (700 out of 1523), which is only slightly over the $40 \%$ of women who identified as university professors in the 2006 census. Among faculty who identified as female, approximately $13 \%$ were racialized, and among those who were not female, $16 \%$ were racialized. These proportions are again similar to the $13 \%$ and $17 \%$ respectively found in the 2006 census $(\mathrm{Li}, 2012)$. Looking at the proportion of immigrants in the survey, 40\% of respondents identified as immigrants (636 out of 1578). Here, we unfortunately did not have comparative census figures of immigrants among the Canadian professorate, but we note the proportion is higher than the proportion of immigrants in the general population. The high proportion of immigrants in our sample, however, was not surprising given the large number of American professors in Canadian faculties, especially those hired during the 1960 s and 1970 .

In Table 1 we examine the proportion of racialized and non-racialized faculty by gender and immigrant status. We can see that among racialized professors, female faculty accounted for $41 \%$ of professors and among non-racialized faculty, $47 \%$. Moreover of the $40 \%$ of immigrant faculty in the survey, a very high proportion, $74 \%$, were racialized.

Table 1. Racialized and Non-Racialized Faculty by Gender and Immigrant Status

\begin{tabular}{lccc}
\hline & & & $\begin{array}{c}\text { Difference } \\
\text { Female }\end{array}$ \\
Ron-female & 41.0 & 46.9 & -5.9 \\
\hline & 59.0 & 53.1 & $n=1,516$ \\
\hline Immigrant*** & & & \\
Non-immigrant & 74.2 & 34.3 & -39.9 \\
\hline & 25.8 & 65.7 & $n=1,575$ \\
\hline$*=p \leq 0.05$ & & & \\
$* * *=p \leq 0.01$ & & & \\
$* * *=p \leq 0.001$ & & &
\end{tabular}

Table 2 explores whether racialized faculty and female faculty are tenured and promoted to associate professor at the same rate as their non-racialized and non-female counterparts. When this was examined, we observed that racialized faculty were less likely to be tenured when compared to non-racialized faculty (53\% versus 66\%). Racialized faculty were also less likely to be promoted to associate professor than non-racialized faculty (56\% versus $69 \%$ ). An $x^{2}$ test of significance indicates that this difference was statistically significant. For female faculty, we noted that fewer had tenure compared to non-female faculty ( $59 \%$ versus 69\%). With regard to promotion to associate professor, fewer female faculty were promoted compared to non-female faculty (61\% versus $71 \%$ ). These differences were again statistically significant. 


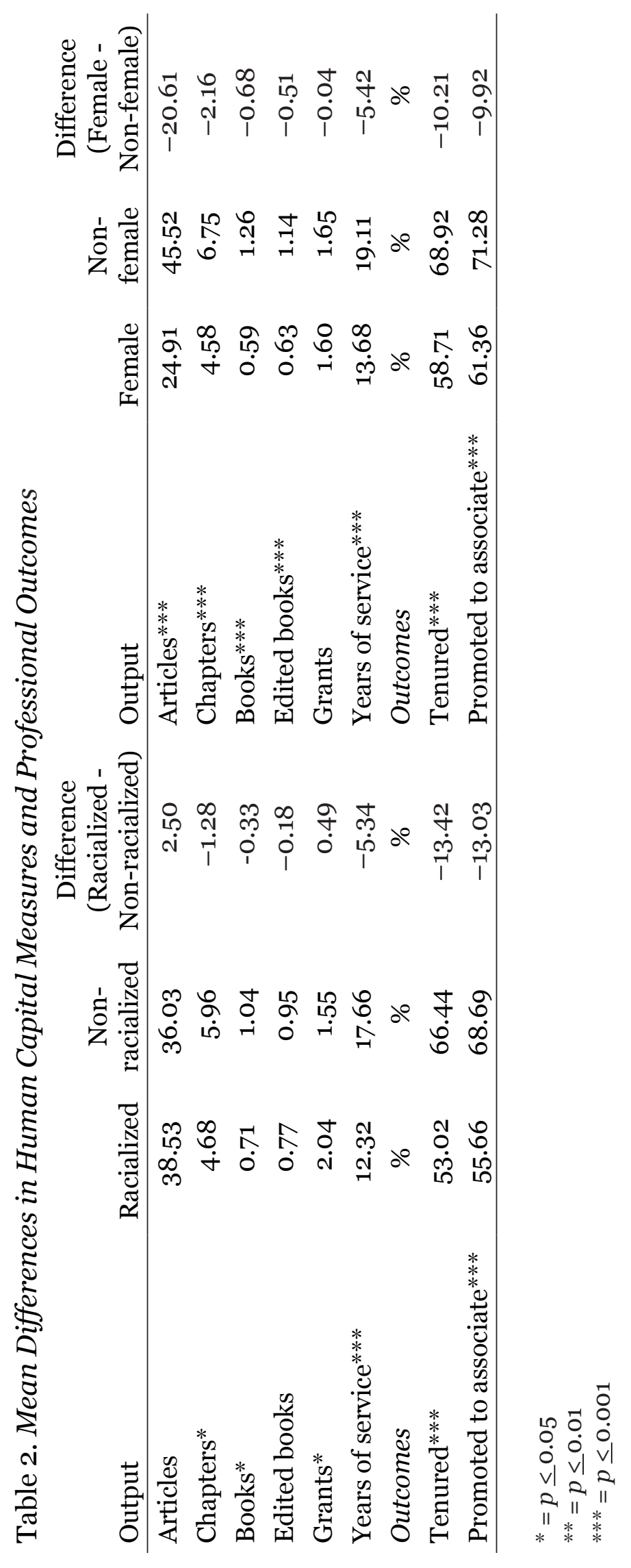


We next considered measures of human capital. Table 2 compares mean differences in the number of refereed articles, book chapters, books, edited books, and awarded research grants between racialized and non-racialized faculty as well as between female and non-female faculty. On average, racialized faculty published more refereed articles and acquired more research grants compared to their non-racialized counterparts. Racialized faculty published three more journal articles, on average, than non-racialized faculty. However, racialized faculty published fewer book chapters, books, and edited books than non-racialized faculty. When we examine statistical significance (using a $t$-test), we see that chapters, books, and research grants were all statistically significant. As with other research on human capital and the tenure and promotion of racialized faculty, we had mixed findings.

When differences between females and non-females were analyzed, also in Table 2, we found that females published fewer refereed articles, book chapters, books, and edited books. Female faculty also acquired fewer research grants compared to their non-female counterparts. The most stark finding here was that non-female faculty published an average of 21 more refereed articles than female faculty. As for statistical significance, a $t$-test indicated that all the variables were significant except for research grants. Again, as with other research on human capital, we found that female faculty were less "productive" in these measures than those who did not identify as female. However, as the literature review suggested, cultural or identity taxation may account for why this is the case.

In Table 2, we also considered years of service as another measure of human capital. When this was examined, we found that racialized faculty and female faculty had fewer years of experience compared to their non-racialized and non-female counterparts. The differences were statistically significant. The data show that this aspect of human capital may be associated with the lower rates of tenure and promotion among racialized and female faculty.

In Table 3, we examined cultural or identity taxation by comparing faculty perceptions of their annual teaching load, graduate supervision of students, and administrative load. When this was examined we found that a smaller proportion of racialized faculty felt their annual teaching load (22\% versus 24\%) and administrative load (38\% versus 44\%) was higher compared to non-racialized faculty. In contrast, a larger proportion of racialized faculty felt they had a higher load of supervision of graduate students than non-racialized faculty (32\% versus 30\%). This offered mixed results on the impact of cultural taxation and was counter to the conclusions of other studies. However, most of the existing research on cultural taxation tends to be qualitative case studies, and this may account for the differences in results. When we looked at identity taxation, a greater proportion of female faculty felt that their teaching load and administrative load was higher compared to non-female faculty. However, more non-female faculty felt their supervision load of graduate students was higher. An $x^{2}$ test indicated that none of these differences were statistically significant. Such results were contrary to those found in existing literature on identity taxation. But again, we note that those studies tended to be qualitative and focused on a smaller number of cases.

So far we have mixed evidence to support human capital and cultural taxation arguments. In Table 4, we examined how the two explanations work in conjunction through logistic regression analysis presented in four models. In Model 1, we regressed whether or not one was tenured on measures of racialized, female, human capital and cultural 
覀

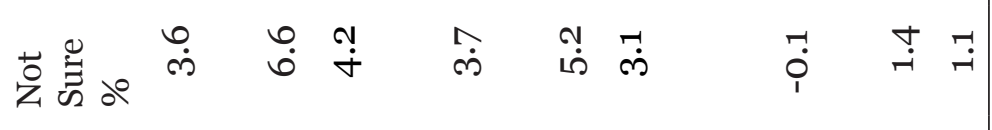

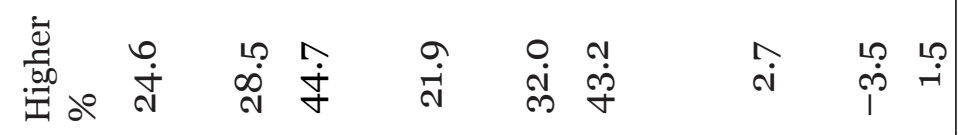

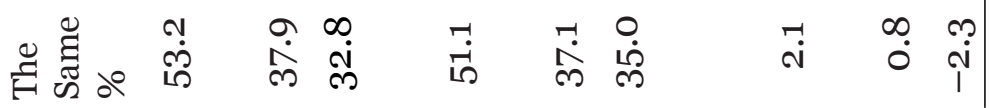

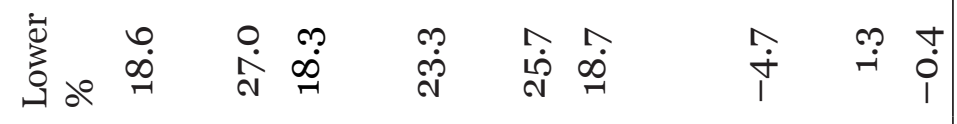

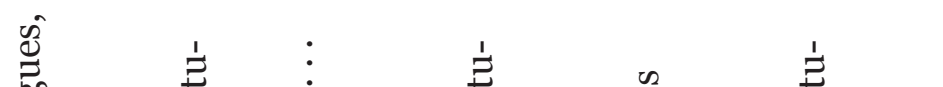

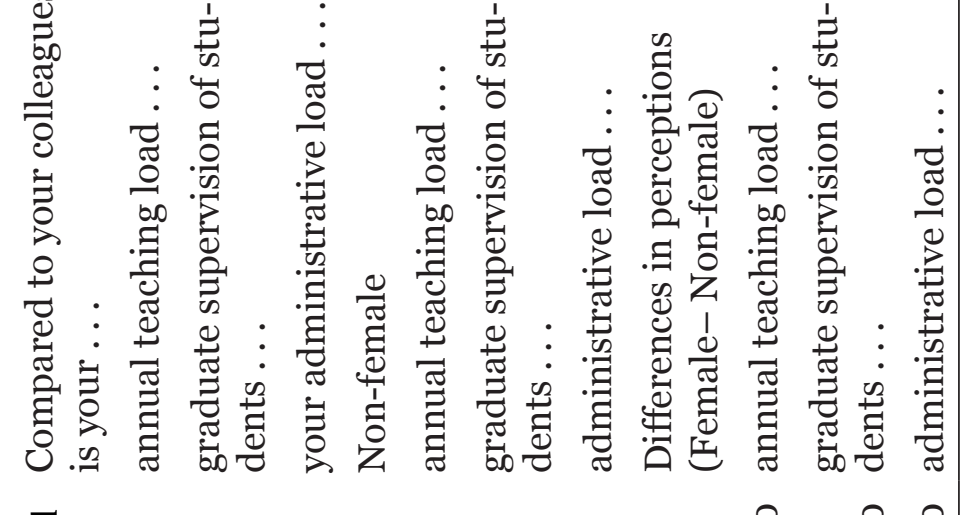

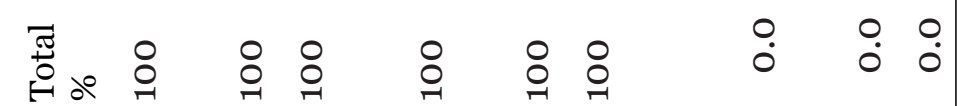

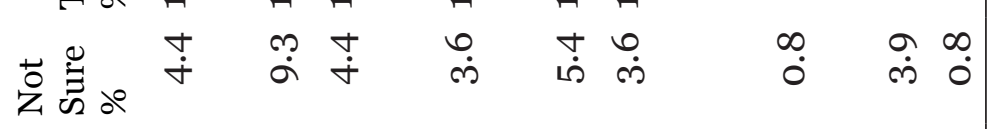

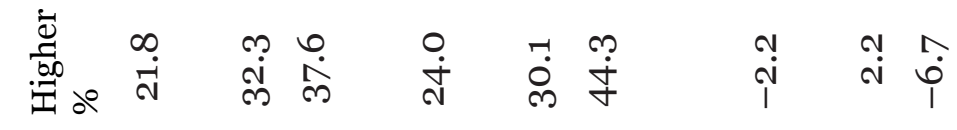

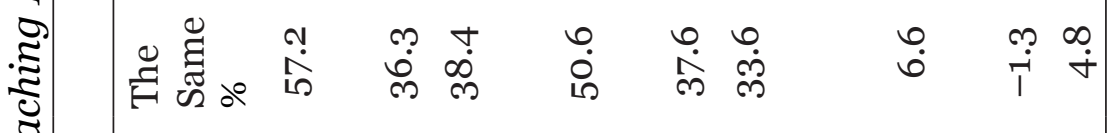

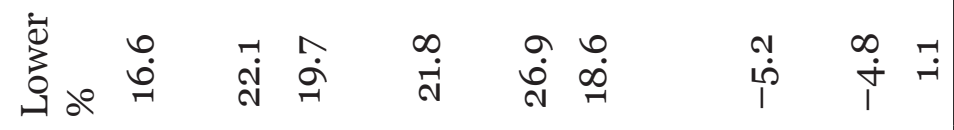

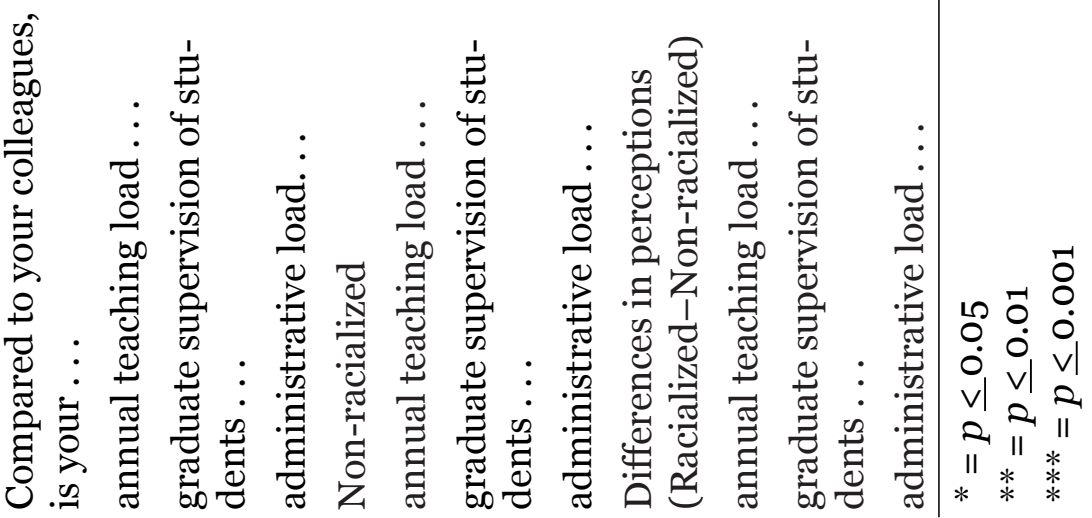




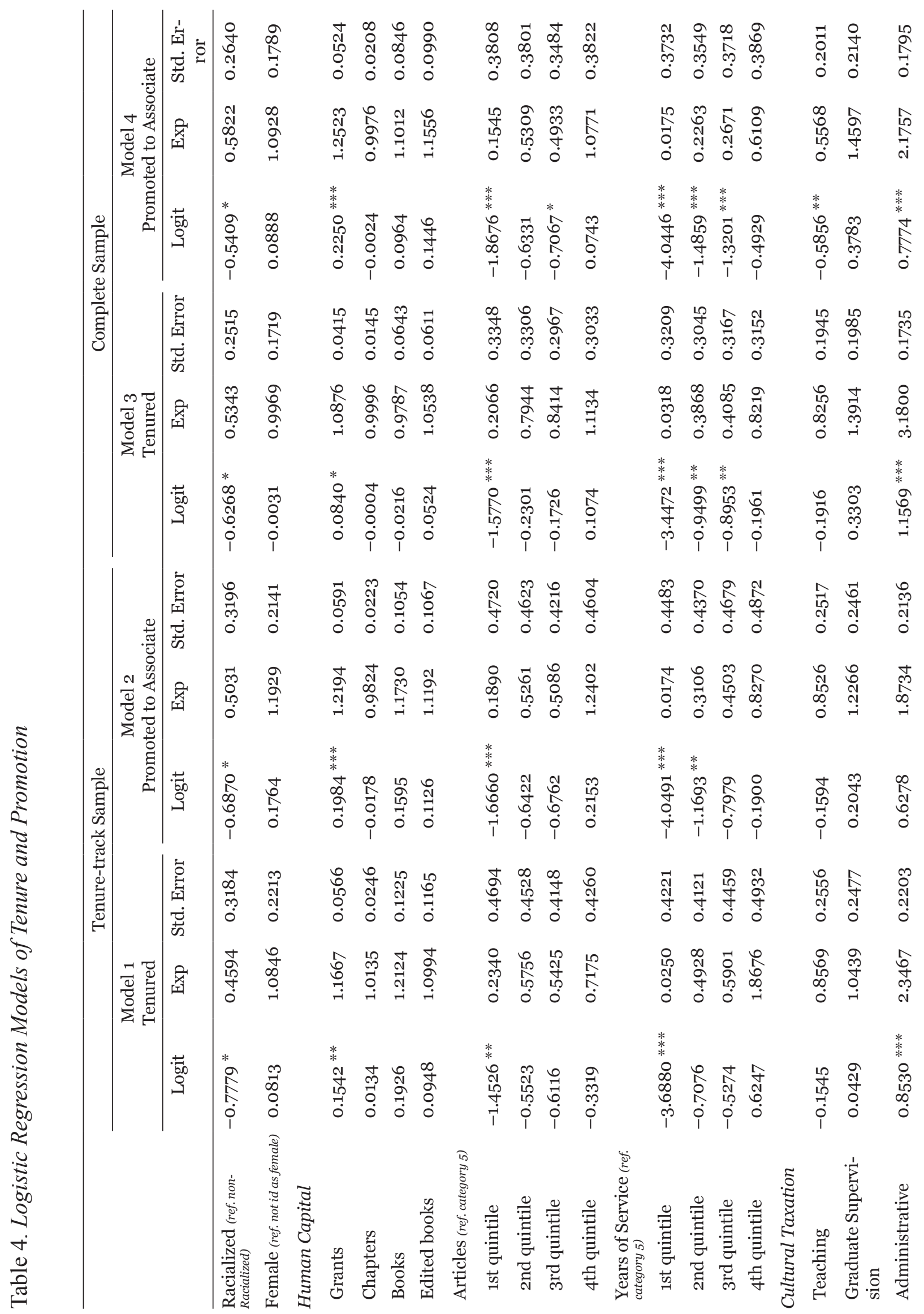




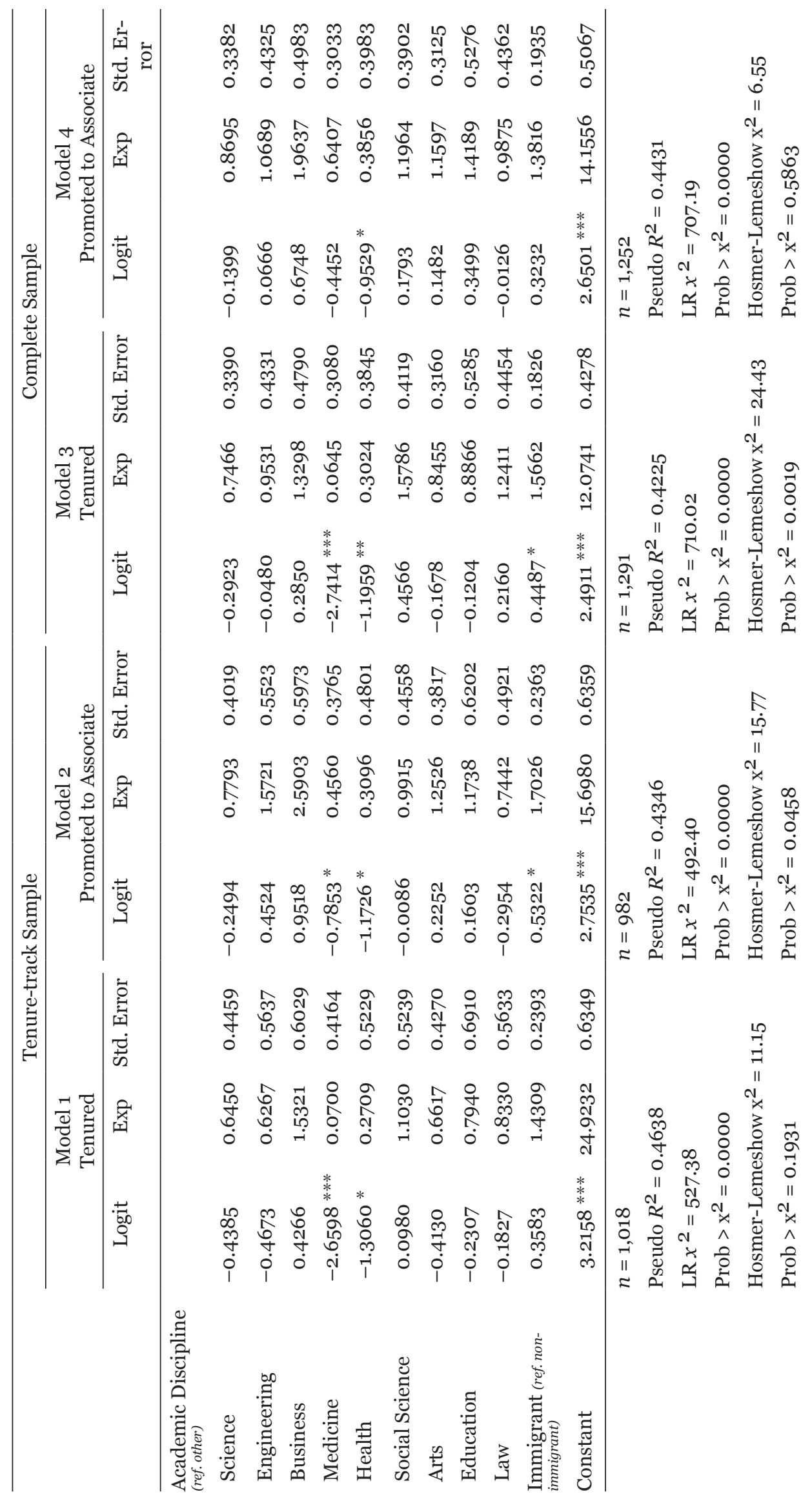


taxation, while also considering controls on a reduced sample consisting of only those on tenure-track. When this was done we saw that racialized faculty had 54\% lower odds of being tenured than non-racialized faculty, even after controlling for human capital and cultural taxation. These differences were statistically significant. For female faculty there was almost no difference, and it was not statistically significant.

When human capital measures were considered, we saw that having a higher number of research grants resulted in greater odds of being tenured, increasing them by about $17 \%$. As expected, when we examined refereed articles, we discerned that having fewer published articles had a negative and statistically significant impact on being tenured. Also, fewer years of service resulted in lower odds of being tenured. Faculty in the quintile with the fewest years of service had a $98 \%$ lower odds of having tenure than those with the most experience. It appears that human capital has a consistent effect on being tenured.

With regard to cultural taxation, we observed that faculty who felt their administrative load was higher had $135 \%$ higher odds of being tenured. The variables measuring perceptions of teaching load and supervision load of graduate students were not statistically significant. Such findings do not support cultural taxation as a factor affecting tenure. Quite the opposite, it appears that those who did more administrative work were better rewarded.

When academic discipline and immigrant status were considered we found that both had an effect on being tenured. Those working in medicine and health had lower odds of being tenured (93\% and $73 \%$ respectively). This is not surprising, given that these fields often do not offer tenure as an outcome, and many teaching in these faculties are practising physicians. There was no significant difference between immigrants and non-immigrants in terms of being tenured.

In Model 2, we examined promotion to associate professor. Here we observed that even after controlling for human capital, cultural taxation, academic discipline, and immigrant status, racialized faculty had $50 \%$ lower odds of being promoted to associate professor than non-racialized faculty. These differences were also statistically significant. Again, this was not the case for female faculty. As with Model 1, when looking at human capital measures, we saw that having more research grants and refereed articles resulted in higher odds of promotion to associate professor. We also found that years of service also increased the odds. When looking at cultural or identity taxation measures in Model 2 , we found that none were statistically significant for promotion. In terms of academic discipline, those working in the field of medicine and health had significantly lower odds of being promoted, compared to other fields. Faculty who identified as immigrants had $70 \%$ higher odds of being promoted to associate professor, compared to non-immigrants. As Table 1 shows, almost two thirds of these professors are racialized. We recognize that the other third are from the dominant group.

The models presented so far look only at faculty in tenure-track positions. However, in some Canadian universities tenure and promotion are not paired and in some fields limited-term professors are appointed at higher ranks. Thus, it is worth looking at all faculty members, irrespective of whether or not they are on a tenure track. For this reason, Models 3 and 4 of Table 4 look at the complete sample. Here we see similar results for tenure and promotion to associate professor. Variables have the same general relationships. To test the robustness of our findings we ran 20 additional models (available from the second author, upon request). In our first check we examined the interaction of racialized faculty with female faculty to discern whether being tenured and promoted differs for racialized, 
female faculty. We did this because research has demonstrated that racialized female faculty face double discrimination and, thus, experience a unique set of challenges (Henry, 2012; Henry \& Tator, 2012; Kobayashi, 2009; Ryu, 2008; Sutherland, 1990; Trower \& Bleak, 2004). When this was run in the model the interaction was not statistically significant. Moreover, other variables in the model performed similarly to those reported in Table 4. This was the case for both the full and tenure-track-only samples. Therefore, our study did not find that racialized women experienced greater disadvantage. In our second robustness check, we looked at an interaction between racialized and immigrant faculty. We did this to examine whether tenure and promotion differs for racialized immigrant faculty. Again the interaction was not statistically significant in the tenure-track-only sample. Other variables operated in a similar fashion to models reported above. In a third robustness check, we also examined models with a reduced set of disciplines, looking at STEM (Science, Technology, Mathematics, and Engineering) versus other disciplines. This did not affect the significance of the disadvantage for racialized faculty being tenured but being racialized was no longer significant for promotion to associate professor. In our last robustness check, we examined an interaction between racialized faculty and STEM disciplines. As with other interactions, the term was not significant. We took the findings of the robustness checks to mean that the significance of being racialized had a consistent and direct effect on being tenured and promoted.

Overall, the effects of human capital were robust and the effects of cultural or identity taxation had mixed results. We also concluded that, even after controlling for human capital and cultural taxation as well as academic discipline and immigrant status, racialized faculty have unexplained differences in their odds of being tenured and promoted.

\section{Conclusion}

To our knowledge, our study is the first Canadian study to examine tenure and promotion of racialized faculty using large-scale quantitative data. Also, it is the first study to simultaneously examine both explanations of human capital and cultural taxation and the roles they play in the tenure and promotion process for racialized and female faculty. Our results demonstrate that racialized faculty exceed non-racialized faculty in attaining research grants and publishing journal articles. Yet, we see that racialized faculty are not tenured or promoted at the same rate as non-racialized faculty and are, in fact, less likely to be in either situation. We find these differences remain even after controlling for human capital, cultural taxation, and academic discipline. It should be noted that currently there is no national data on refusal rates for tenure (Acker, Webber, \& Smyth, 2012). Moreover, there is no easy way to document cases where individuals have left a university position before coming up for tenure, left after being denied tenure, or appealed and eventually received tenure after a refusal. Therefore, it is hard to make a commentary on the rates at which racialized faculty receive tenure. However, we feel that this actually strengthens our findings and that the case for racialized faculty might be even worse than we portray through our data since we cannot, for example, account for individuals who did not receive tenure and left the university.

Our study finds that human capital measures are important and consistent factors in increasing the odds of academic achievement, but they do not adequately explain disparities in promotion and tenure rates for racialized faculty. This is consistent with the literature from Canada (Nakhaie, 2007) and the US (Perna, 2001a) that illustrates that racial 
differences for faculty remain even after controlling for human capital. With respect to cultural taxation, this appears to be less of a barrier to tenure than anticipated in existing research in both Canada and the US (Hirshfield \& Joseph, 2012; Jackson, 2004; Joseph \& Hirshfield, 2011; Menges \& Exum, 1983; Misra et al., 2011; Nettles et al., 2000; Odhiambo \& Charoenpanitkul, 2011; Samble, 2008; Villalpando \& Bernal, 2002).

Given the fact that the effect of race remains, even after controlling for human capital, cultural taxation, and other controls, future researchers may want to focus on the role of discrimination in the tenure and promotion process for racialized faculty, which can be difficult to capture through a statistical model. This finding and conclusion is in line with Nakhie (2007). Qualitative studies from Canada demonstrate that one reason racialized faculty feel that they do not receive tenure and promotion at the same rate as non-racialized faculty is due to the discrimination they face (Henry \& Tator, 2012; Monture, 2009). In particular, racialized faculty indicate that they faced discrimination through the devaluation of the research they conduct and career paths they pursue (Henry, 2012; Henry \& Tator, 2012; Kobayashi, 2009). Baez (1998) found that racialized faculty in the US felt that their research was not rewarded in the same manner during tenure review because it did not often conform to mainstream research. Others have shown that research conducted by minority scholars in the US is often perceived as less rigorous and prestigious compared to research by other scholars (Boyd, Cintron, \& Alexander-Snow, 2010). Yet others, such as Henry and Tator (2012), have established that Eurocentric knowledge is more validated and valued in Canadian academia (Henry \& Tator, 2012; Monture, 2009), as can be seen in rewards for publishing in "mainstream" venues and rewarding "mainstream" career tracks, based on publication and grants. Our data and results suggest that there is macro support for these qualitative insights.

With respect to female faculty, we found they publish less than male faculty, and this is consistent with other research in Canada and the US (Bellas \& Toutkoushian, 1999; Evans \& Bucy, 2010; Hesli \& Lee, 2011; Long \& Fox, 1995; Nakhaie, 2002; Sax, Hagedom, Arredondo, \& Dicrisi III, 2002). This was the case for articles, books, book chapters, and edited books when compared to male faculty. As with other Canadian research (CAUT, 2008, 2010), we also discovered that female faculty are less likely to be found in tenured positions and as associate professors. However, these differences become non-significant when we control for measures of human capital, cultural taxation, and academic discipline. Therefore, our findings demonstrate that equity efforts may be working for female faculty in Canada but are not having the same effect for racialized faculty.

For this reason, we suggest that it may prove prudent to examine what has changed the trajectory of academic reward for women over the last few decades since those mechanisms are likely ones that can be used to generate a more equitable reward system for racialized faculty. It is clear that human capital recognition and reward is part of the answer, but our analysis also suggests that other factors also need to be pursued, such as advocacy and recognition of the need to continue to use equity policies to overcome disparities.

\section{Acknowledgements}

Our research was funded by the Social Science and Humanities Research Council of Canada as a part of a project looking at race and racialization in Canadian universities. We would like to thank Frances Henry, Audrey Kobayashi, Carl James, Peter Li, Malinda Smith 
and Ena Dua for inviting us to be part of the project and for offering valuable insights as we developed our research. We would also like to thank the anonymous reviewers and editors of this journal for their critical feedback, which has made our paper stronger.

\section{References}

Acker, S., Webber, M., \& Smyth, E. (2012). Tenure troubles and equity matters in Canadian academe. British Journal of Sociology of Education, 33(5), 743-761.

Antonio, A. L. (2002). Faculty of color reconsidered: Reassessing contributions to scholarship. Journal of Higher Education, 73(5), 582-602.

Baez, B. (1998). Negotiating and resisting racism: How faculty of color construct promotion and tenure. (ERIC Document Reproduction Service no. ED430420). Retrieved from http://files.eric.ed.gov/fulltext/ED430420.pdf

Bellas, M. L., \& Toutkoushian, R. K. (1999). Faculty time allocations and research productivity: Gender, race and family effects. Review of Higher Education, 22(4), 367-390.

Boyd, T., Cintron, R., \& Alexander-Snow, M. (2010). The experience of being a junior minority female faculty member. Forum on Public Policy, 2, 1-23.

Canadian Association of University Teachers [CAUT]. (2008). The tenure gap: Women's university appointments, 1985-2005. CAUT Equity Review, 4, 1-4.

CAUT. (2010). The changing academy? A portrait of Canada's university teachers. CAUT Education Review, 12(1), 1-6.

Chen, Z., \& Ferris, J.S. (1999). A theory of tenure for the teaching university. Australian Economic Papers, 38(1), 9-25.

Comack, E. (2012). Racialized policing: Aboriginal people's encounters with the police. Halifax, NS: Fernwood Publishing.

Cook, C., Heath, F., \& Thompson, R. L. (2000). A meta-analysis of response rates in web- or internet-based surveys. Educational and Psychological Measurement, 6o(6), 821-836.

Cora-Bramble, D., Zhang, K., \& Castillo-Page, L. (2010). Minority faculty members' resilience and academic productivity: Are they related? Academic Medicine, 85(9), 14921498.

Dua, E. (2008). Thinking through anti-racism and Indigenity in Canada. Ardent Review, 1, 31-35.

Dua, E., \& Bhanji, N. (2012). Exploring the potential of data collected under the Federal Contractors Programme to construct a national picture of visible minority and Aboriginal faculty in Canadian universities. Canadian Ethnic Studies, 44(2), 49-74.

Etzkowitz, H., Kemelgor, C., \& Uzzi, B. (2000). Athena unbound: The advancement of women in science and technology. Cambridge, UK: Cambridge University Press.

Evans, H. K., \& Bucy, E. P. (2010). The representation of women in publication: An analysis of political communication and the International Journal of Press/Politics. PS: Political Science and Politics, 43(2), 295-301. 
Fairweather, J.S. (1993). Academic values and faculty rewards. Review of Higher Education, 17(1), 43-68.

Fairweather, J.S. (2002). The mythologies of faculty productivity: Implications for institutional policy and decision making. Journal of Higher Education, 73(1), 26-48.

Galabuzi, G. (2006). Canada's economic apartheid: The social exclusion of racialized groups in the new century. Toronto, ON: Canadian Scholar's Press.

Ginther, D. K., \& Hayes, K. J. (2003). Gender differences in salary and promotion for faculty in the humanities 1977-95. Journal of Human Resources, 38(1), 34-73.

Harper, E. P., Baldwin, R. G., Gansneder, B. G., \& Chronister, J. L. (2001). Full-time women faculty off the tenure track: Profile and practice. The Review of Higher Education, 24(3), 237-257.

Hattie, J., \& Marsh, H. W. (1996). The relationship between research and teaching: A meta-analysis. Review of Educational Research, 66, 507-542.

Henry, F. (2012). Indigenous faculty at Canadian universities: Their stories. Canadian Ethnic Studies, 44(2), 101-132.

Henry, F., Choi, A., \& Kobayashi, A. (2012). The representation of racialized faculty at selected Canadian universities. Canadian Ethnic Studies, 44(2), 1-12.

Henry, F., \& Tator, C. (2009). Theoretical perspectives and manifestations of racism in the academy. In F. Henry \& C. Tator (Eds.), Racism in the Canadian university: Demanding social justice, inclusion, and equity (pp. 22-59). Toronto, ON: University of Toronto Press.

Henry, F., \& Tator, C. (2012). Interviews with racialized faculty members in Canadian universities. Canadian Ethnic Studies, 44(2), 75-99.

Hesli, V. L., \& Lee, J. M. (2011). Faculty research productivity: Why do some of our colleagues publish more than others? PS: Political Science and Politics, 44(2), 393-408.

Hirshfield, L. E., \& Joseph, T. D. (2012). 'We need a woman, we need a black woman': Gender, race, and identity taxation in the academy. Gender and Education, 24(2), 213227.

Jackson, J. (2004). The story is not in the numbers: Academic socialization and diversifying the faculty. NWSA Journal, 1, 172-185.

Jackson, J. F. L. (2008). Race segregation across the academic workforce-Exploring factors that may contribute to the disparate representation of African American men. American Behavioral Scientist, 51(7), 1004-1029.

Johnson, B. J., \& Harvey, W. B. (2002). The socialization of Black college faculty: Implications for policy and practice. Review of Higher Education, 25(3), 297-314.

Jones, G., Weinrib, J., Metcalfe, A. S., Fisher, D., Rubenson, K., \& Snee, I. (2012). Academic work in Canada: Perceptions of early-career academics. Higher Education Quarterly, 66(2), 189-206.

Joseph, T. D., \& Hirshfield, L. E. (2011). Why don't you get somebody new to do it? Race and cultural taxation in the academy. Ethnic and Racial Studies, 34(1), 121-141. 
Kobayashi, A. (2009). Now you see them, how you see them: Women of colour in Canadian academia. In F. Henry \& C. Tator (Eds.), Racism in the Canadian University: Demanding Social Justice, Inclusion, and Equity (pp. 60-75). Toronto, ON: University of Toronto Press.

Larivière, V., Vignola-Gagné, E., Villeneuve, C., Gélinas, P., \& Gingras, Y. (2011). Sex differences in research funding, productivity and impact: An analysis of Quebéc university professors. Scientometrics, 87(3), 483-498.

Leslie, D. W. (2002). Resolving the dispute: Teaching is academe's core value. The Journal of Higher Education, 73(1), 49-73.

Long, J. S., \& Fox, M. F. (1995). Scientific careers: Universalism and particularlism. Annual Review of Sociology, 21, 45-71.

Li, P. (1992). Race and gender bases of class fractions and their effects on earnings. Canadian Review of Sociology and Anthropology, 29(4), 488-510.

Li, P. (2012). Differences in employment income of university professors. Canadian Ethnic Studies, 44(2), 39-48.

Marschke, R., Laursen, S., McCarl Nielsen, J., \& Dunn-Rankin, P. (2007). Demographic inertia revisited: An immodest proposal to achieve equitable gender representation among faculty in higher education. Journal of Higher Education, 78(1), 1-26.

Menges, R. J., \& Exum, W. H. (1983). Barriers to the progress of women and minority faculty. Journal of Higher Education, 54(2), 123-144.

Misra, J., Lundquist, J., Holmes, E., \& Agiomavritis, S. (2011). The ivory ceiling of service work. Academe Online. Retrieved from http://www.aaup.org/article/ivoryceiling-service-work\#.VdkXSrH1A2Q

Monture, P. (2009). 'Doing academia differently': Confronting 'Whiteness' in the university. In F. Henry \& C. Tator (Eds.), Racism in the Canadian university: Demanding social justice, inclusion, and equity (pp. 76-105). Toronto, ON: University of Toronto Press.

Nakhaie, M. R. (2002). Gender differences in publication among university professors in Canada. Canadian Review of Sociology and Anthropology, 39(2), 151-179.

Nakhaie,M.R.(2007).Universalism, ascription and academic rank: Canadian professors, 1987-2000. Canadian Review of Sociology and Anthropology, 44(3), 361-386.

Nettles, M. T., \& Perna, L. W. (1995). Sex and race differences in faculty salaries, tenure, rank, and productivity: Why on average do women, African Americans, and Hispanics have lower salaries, tenure, and rank? Paper presented at the Annual Meeting of the Association for the Study of Higher Education. Retrieved from ERIC database. (ED 391402) http://files.eric.ed.gov/fulltext/ED391402.pdf

Nettles, M. T., Perna, L. W., Bradburn, E. M., \&Zimbler, L. (2000). Salary, promotion, and tenure status of minority and women faculty in U.S. colleges and universities. U.S. Department of Education, National Center for Education Statistics (NCES 2000-173). Retrieved from http://nces.ed.gov/pubs200o/2000173.pdf

Nulty, D. D. (2008). The adequacy of response rates to online and paper surveys: What can be done? Assessment \& Evaluation, 33(3), 301-314. 
Odhiambo, E., \& Charoenpanitkul, C. (2011). Marginalization: A continuing problem in higher education. In V. Yenika-Agbaw \& A. Hidalgo-de Jesús (Eds.), Race, Women of Color, and the State University System: Critical Reflections (pp. 64-81). Lanham, MD: University Press of America.

Ornstein, M., Stewart, P., \& Drakich, J. (1998). The status of women in Canadian universities 1957-95. Education Quarterly Review, 5(2), 29-47.

Ornstein, M., Stewart, P., \& Drakich, J. (2007). Promotion at Canadian universities: The intersection of gender, discipline, and institution. Canadian Journal of Higher Education, 37(3), 1-25.

Padilla, A. M. (1994). Ethnic minority scholars, research, and mentoring: Current and future issues. Educational Researcher, 23(4), 24-27.

Park, T. (2011). Do faculty members get what they deserve? A review of the literature surrounding the determinants of salary, promotion and tenure. Journal of the Professoriate, 66(1), 28-47.

Pearson, W. (1985). Black scientists, White society and colorless science: A study of universalism in American science. Millwood, NY: Associated Faculty Press.

Pendakur, K., \& Pendakur, R. (2002). Colour my world: Have earning gaps for Canadian-born ethnic minorities changed over time? Canadian Journal of Economics, $31(3), 518-548$.

Perna, L. W. (2001a). Sex and race differences in faculty tenure and promotion. Research in Higher Education, 42(5), 541-567.

Perna, L. W. (2001b). Sex differences in faculty salaries: A cohort analysis. Review of Higher Education, 42(3), 283-307.

Perna, L. W. (2005). Sex differences in faculty tenure and promotion: The contribution of family ties. Research in Higher Education, 46(3), 277-307.

Porter, S. R., Toutkoushian, R. K., \& Moore J. V., III. (2008). Pay inequities for recently hired faculty, 1988-2004. The Review of Higher Education, 31(4), 465-487.

Ramos, Howard. 2012. Does how you measure representation matter? Assessing the persistence of Canadian universities' gendered and colour coded vertical mosaic. Canadian Ethnic Studies 44(2): 13-38.

Ryu, M. (2008). Minorities in higher education 2008: Twenty-third status report. Washington, DC: American Council on Education.

Samble, J. (2008). Female faculty: Challenges and choices in the United States and beyond. New Directions for Higher Education, 143, 55-62.

Sax, L. J., Hagedom, L. S., Arredondo, M., \& Dicrisi, F.A., III. (2002). Faculty research productivity: Exploring the role of gender and family-related factors. Research in Higher Education, 43(4), 423-445.

Smart, J. C. (1991). Gender equity in academic rank and salary. Review of Higher Education, 14(4), 511-526. 
Spafford, M. M., Nygaard, V. L., Gregor, F., \& Boyd, M. A. (2006). "Navigating the different spaces": Experiences of inclusion and isolation among racially minoritized faculty in Canada. Canadian Journal of Higher Education, 36(1), 1-27.

Stack, S. (2004). Gender, children and research productivity. Research in Higher Education, 45(8), 891-920.

Statistics Canada. (2013). Immigration and ethnocultural diversity in Canada: National Household Survey, 2011. (Catalogue no. 99-010-X2011001). Retrieved from http://www12.statcan.gc.ca/nhs-enm/2011/as-sa/99-010-x/99-010-X2011001-eng.pdf

Stewart, A. (2009). You must be a basketball player: Rethinking integration in the university. Halifax, NS: Fernwood Publishing.

Stewart, P., Ornstein, M., \& Drakich, J. (2009). Gender and promotion at Canadian universities. Canadian Review of Sociology, 46(1), 59-85.

Sutherland, M. E. (1990). Black faculty in White academia: The fit is an uneasy one. Western Journal of Black Studies, 14(1), 17-23.

Synnott, A., \& Howes, D. (1996). Canada's visible minorities: Identity and representation. In V. Amit-Talai \& C. Knowles (Eds.), Re-Situating identities: The politics of race, ethnicity and culture (137-151). Peterborough: Broadview Press.

Toutkoushian, R. K. (1998). Racial and marital status differences in faculty pay. Journal of Higher Education, 69(5), 513-541.

Toutkoushian, R. K. (1999). The status of academic women in the 1990s: No longer outsiders, but not yet equals. Quarterly Review of Economics and Finance, 39, 679-698.

Trower, C.A., \& Bleak, J. L.(2004). The study of new scholars. Gender: Statistical Report [Universities]. Cambridge, MA: Harvard Graduate School of Education. Retrieved from http://sites.gse.harvard.edu/sites/default/files/coache/files/sns_report_gender_o.pdf

Valian, V. (1998). Why so slow? The advancement of women. Cambridge, MA: MIT Press.

Villalpando, O., \& Bernal, D. D. (2002). A critical race theory analysis of barriers that impede the success of faculty of color. In W. W. Smith, P. G. Altbach \& K. Lomotey (Eds.), The racial crisis in American higher education: Continuing challenges for the twentyfirst century (pp. 243-269). Albany, NY: SUNY Press.

Weinberg, S.L. (2008). Monitoring faculty diversity: The need for a more granular approach. Journal of Higher Education, 79(4), 365-387.

\section{Notes}

1 The full survey is available upon request to the second author.

2 Visible minority status is defined by Statistics Canada according to the Employment Equity Act. The Act refers to visible minorities as "persons, other than Aboriginal peoples, who are non-Caucasian in race or non-white in colour" (S.C.1995, c.44). Categories include: Arab, Black, Chinese, Filipino, Japanese, Korean, Latin American, South Asian, Southeast Asian, West Asian, other visible minority, and multiple (mixed) visible minority.

3 The 2006 census data was used because it was the last comprehensive Canadian census. It has since been replaced with the National Household Survey, which is arguably less accurate in measuring small populations. 


\section{Contact Information}

Howard Ramos, Department of Sociology and Social Anthropology

Dalhousie University

howard.ramos@dal.ca

Rochelle Wijesingha is a PhD candidate in the Department of Sociology at McMaster University. Her research interests include the social determinants of health, higher education, racial and ethnic relations, policing, and social statistics.

Howard Ramos is Associate Dean of Research in the Faculty of Arts and Social Sciences and Professor of Sociology at Dalhousie University. His research focuses on issues of social justice broadly defined. He has published on issues of ethnicity and race, social movements, and social change. 